\title{
Glycosaminoglycan Synthesis by Wilms' Tumor
}

\author{
JOHN J. HOPWOOD AND ALBERT DORFMAN ${ }^{(39)}$ \\ Departments of Pediatrics and Biochemistry, Joseph P. Kennedy, Jr. Mental Retardation Research Center, \\ University of Chicago, Pritzker School of Medicine, Chicago, Illinois, USA
}

\begin{abstract}
Summary
Wilms' tumor contains approximately $1 \mathrm{mg}$ hyaluronic acid and approximately $0.3 \mathrm{mg}$ sulfated glycosaminoglycan per $\mathrm{g}$ tissue. Minced tumor and cells cultured from the tumor incorporate labeled acetate and glucosamine into hyaluronic acid and sulfated glycosaminoglycans. A particulate enzyme preparation derived from the tumor catalyzed the transfer of GlcUA or GlcNAc from UDP-GIcUA or UDP-GlcNAc at a rate of approximately $20 \mathrm{nmol} / \mathrm{hr} / \mathrm{mg}$ protein to produce high molecular weight hyaluronic acid chains. The urine and plasma of a Wilms' tumor patient contained approximately $20 \mathrm{mg}$ hyaluronic acid and $8 \mathrm{mg}$ sulfated glycosaminoglycan/100 ml, respectively. It appears that this higher than normal level of circulating glycosaminoglycan is synthesized by the Wilms' tumor.
\end{abstract}

\section{Speculation}

The conversion of normal cells to malignant cells results in changes in regulation of glycosaminoglycan synthesis. Of special interest is the same qualitative change in hyaluronic acid synthesis in Wilms' tumor as observed in SV40-transformed human fibroblasts.

Wilms' tumor (nephroblastoma), one of the most frequent solid malignant tumors of childhood, almost exclusively arises from the kidney and is contained, in part, by the renal capsule. Deutsch (7), Tomasi et al. (29), and Morse and Nussbaum (21) have reported the presence of hyaluronic acid in the serum of patients with this neoplasm. Definite proof that this tumor synthesizes hyaluronic acid has not been reported, although Allerton et al. (1) were able to isolate hyaluronic acid from freshly excised tumor. In this communication evidence is presented indicating that hyaluronic acid and other glycosaminoglycans are actively synthesized by Wilms' tumor.

\section{MATERIALS AND METHODS}

\section{MATERIALS}

Modified Eagle's medium (18), fetal calf, calf serum, and Hanks' balanced salt solution were obtained from Grand Island Biological Co. Gentamycin was purchased from the Schering Corp. Carrier chondroitin 4-sulfate was a gift of Dr. J. A. Cifonelli.

The radioactive precursors, $\mathrm{H}_{2}{ }^{35} \mathrm{SO}_{4}$, carrier-free $(43 \mathrm{Ci} / \mathrm{mg})$, sodium $\left[U^{3} \mathrm{H}\right]$ acetate $(100 \mathrm{Ci} / \mathrm{mol})$, and UDP- $\left[{ }^{14} \mathrm{C}\right] \mathrm{GlcUA}(233$ $\mathrm{mCi} / \mathrm{mmol}$ ), were purchased from New England Nuclear Corp. UDP- $\left[{ }^{14} \mathrm{C}\right]$ GlcNAc $(32 \mathrm{Ci} / \mathrm{mol})$ was purchased from Schwarz BioResearch and $\left[{ }^{14} \mathrm{C}\right]$ glucosamine $(58 \mathrm{mCi} / \mathrm{mmol})$ from Amersham/Searle Corp.

Varidase, used as a source of streptococcal hyaluronidase (11), was obtained from Lederle Laboratories. Testicular hyaluronidase $(20,000 \mathrm{IU} / \mathrm{mg})$ was purchased from Leo-Helsinborg Laboratories, Sweden, and chondroitinase $A B C$ and pig skin hyaluronic acid from Miles Laboratories, Inc. Pronase (B grade) and collagenase (sterile, Clostridium histolyticum) were obtained from Calbiochem and Worthington Biochemical Corp., respectively. Twice crystallized papain, prepared from crude enzyme (type II, Sigma) by the procedure of Kimmel and Smith (15), was a gift of Dr. A. C. Stoolmiller.

Sephadex G-50 (fine grade), Sephadex G-200 (fine), and Sepharose 4B were purchased from Pharmacia Fine Chemicals, Uppsala, Sweden, and ECTEOLA-cellulose (Whatman Chromedia ET-11 cellulose; nominal capacity, $0.5 \mathrm{mEq} / \mathrm{g}$ ) from $\mathrm{W}$. and R. Balston Ltd., Maidstone, Kent, UK.

The Wilms' tumor was obtained within $1 \mathrm{hr}$ after its surgical removal. Portions of the tumor were digested with collagenase for isolation of cells or incubated with labeled glycosaminoglycan precursors. The remainder of the tumor was stored at $-20^{\circ}$. Serum and urine samples were obtained preoperatively from another patient with a confirmed Wilms' tumor.

\section{ISOLATION AND CULTURE OF WILMS' TUMOR CELLS}

Four $\mathrm{g}$ tumor were minced and incubated with $2 \mathrm{mg}$ collagenase in $20 \mathrm{ml}$ modified Eagle's medium in two 100-mm Falcon tissue culture dishes (Falcon Plastics, Division of Bio-Quest, Oxnard, CA). After 2 days at $37^{\circ}$ in a humidified atmosphere of $10 \% \mathrm{CO}_{2}$ and $90 \%$ air, the cells and medium were removed from the dishes, centrifuged $(10 \mathrm{~min}$ at $500 \times \mathrm{g})$, and the pellet dispersed in $20 \mathrm{ml}$ modified Eagle's medium containing $10 \%$ fetal calf, $10 \%$ calf serum, and $5 \mu \mathrm{g} / \mathrm{ml}$ gentamycin. This cell suspension was then incubated for 7 days over $0.5 \%$ agar containing the same medium. During this period the cells were fed twice by gently removing them from above the agar gel, centrifuging $(10 \mathrm{~min}$ at $500 \times \mathrm{g})$, resuspending the pelleted cells in fresh medium, and transfering this suspension to freshly prepared agar dishes. Floating cells were then transferred to 100-mm Falcon plastic dishes and fed every 2-3 days for about 2 weeks to yield approximately $10^{7}$ cells/dish. Cells were grown at $37^{\circ}$ in a humidified atmosphere of $10 \% \mathrm{CO}_{2}$ and $90 \%$ air.

\section{GLYCOSAMINOGLYCAN SYNTHESIS IN CULTURED WILMS' TUMOR} CELLS

On the last day of culture, cells were suspended in $10 \mathrm{ml}$ medium and incubated for $24 \mathrm{hr}$ at $37^{\circ}$ with either $25 \mu \mathrm{Ci}$ $\mathrm{H}_{2}{ }^{35} \mathrm{SO}_{4}$ and $25 \mu \mathrm{Ci}\left[{ }^{3} \mathrm{H}\right]$ acetate $/ \mathrm{ml}$ or $20 \mu \mathrm{Ci}\left[{ }^{14} \mathrm{C}\right.$ ]glucosamine/ $\mathrm{ml}$ medium. Cells and medium were collected and the labeled glycosaminoglycans were solubilized by alkali treatment after the addition of $1 \mathrm{mg}$ each of carrier hyaluronic acid and chondroitin sulfate. Alkali treatment was performed at $4^{\circ}$ for 5 days in $0.5 \mathrm{M} \mathrm{KOH} \mathrm{(25).} \mathrm{Samples} \mathrm{were} \mathrm{neutralized} \mathrm{with} \mathrm{acetic}$ acid and dialyzed against water at $4^{\circ}$.

\section{GLYCOSAMINOGLYCAN SYNTHESIS IN WILMS' TUMOR MINCES}

Two $\mathrm{g}$ Wilms' tumor were finely minced and incubated for 8 hr at $37^{\circ}$ with $5 \mathrm{ml}$ modified Eagle's medium, $1 \mathrm{ml}$ Hanks' balanced salt solution, $300 \mu \mathrm{Ci} \quad \mathrm{H}_{2}{ }^{35} \mathrm{SO}_{4}$, and $300 \mu \mathrm{Ci}$ $\left[{ }^{3} \mathrm{H}\right]$ acetate. Two milliliters of $2.0 \mathrm{M} \mathrm{KOH}$ were added and the incubation was continued at $30^{\circ}$. The reaction was stopped 
after $7 \mathrm{hr}$ by neutralization with acetic acid and the mixture was dialyzed against water at $4^{\circ}$. This mixture was added to $13.5 \mathrm{~g}$ minced Wilms' tumor and stirred at $4^{\circ}$ for $76 \mathrm{hr}$ with $100 \mathrm{ml}$ $0.5 \mathrm{M} \mathrm{KOH}$. The reaction mixture was neutralized with acetic acid and dialyzed against water at $4^{\circ}$. The insoluble residue was removed by centrifugation $(10 \mathrm{~min}$ at $10,000 \times \mathrm{g})$ and part of the supernatant solution was applied to a column $(2 \times 25 \mathrm{~cm})$ of ECTEOLA-cellulose ( $\mathrm{Cl}^{-}$form). Elution after a wash with approximately $150 \mathrm{ml} 0.02 \mathrm{M}$ pyridine acetate $(0.02 \mathrm{M}$ in acetate) was carried out with a linear gradient of $\mathrm{NaCl}$ generated from $500 \mathrm{ml} 0.02 \mathrm{M}$ pyridine acetate $(0.02 \mathrm{M}$ in acetate $), \mathrm{pH}$ 5.0 , and $500 \mathrm{ml} 2.0 \mathrm{M} \mathrm{NaCl}$ in the pyridine-acetate buffer (25).

\section{ANALYSIS OF GLYCOSAMINOGLYCANS}

Glycosaminoglycans were characterized by sequential enzyme and chemical treatments followed by separation of the products on columns $(1 \times 200 \mathrm{~cm})$ of Sephadex G-50 (fine) which were eluted with the $0.2 \mathrm{M}$ pyridine acetate buffer $(0.2 \mathrm{M}$ in acetic acid, pH 5.0).

Labeled glycosaminoglycan fractions were lyophilized to remove pyridine acetate buffer and incubated at $37^{\circ}$ for $24 \mathrm{hr}$ with $3 \mathrm{mg}$ Varidase in $5 \mathrm{ml} 0.01 \mathrm{M}$ phosphate buffer, $\mathrm{pH} 6.0$, containing $0.15 \mathrm{NaCl}(28)$. Testicular hyaluronidase digestions were carried out in a total volume of $5 \mathrm{ml} 0.1 \mathrm{M}$ sodium acetate buffer, pH 5.0, containing $0.15 \mathrm{~N} \mathrm{NaCl}$, using 20,000 IU enzyme (20). Samples were incubated for $6 \mathrm{hr}$ at $37^{\circ}$. Chondroitinase $\mathrm{ABC}$ digestions were performed as described by Saito et al. (26) in $0.08 \mathrm{M}$ Tris-chloride buffer $(0.08 \mathrm{M}$ in chloride), $\mathrm{pH}$ 8.0, using 0.6 unit enzyme. Samples were incubated for $6 \mathrm{hr}$ at $37^{\circ}$ in a total volume of $4 \mathrm{ml}$.

Nitrous acid degradation of glycosaminoglycans was carried out according to the procedure of Lagunoff and Warren (16) by adding $3 \mathrm{ml} 5 \%$ sodium nitrite and $3 \mathrm{ml} 33 \%$ acetic acid to freeze-dried samples, incubating the reaction mixture for $2 \mathrm{hr}$ at $30^{\circ}$, and freeze-drying.

\section{ISOLATION AND ANALYSIS OF GLYCOSAMINOGLYCANS IN SERUM} AND URINE

Serum and dialyzed urine samples were digested with papain at $60^{\circ}$ for $20 \mathrm{hr}(9)$. Glycosaminoglycans were precipitated in the presence of $0.03 \mathrm{M} \mathrm{NaCl}$ by the addition of $10 \%$ cetylpyridinium chloride to the papain digests after dialysis and approximately 6-fold concentration. The precipitate was dissolved in $2.0 \mathrm{M} \mathrm{LiCl}$. Four volumes of ethanol were added to the solution, and the glycosaminoglycan precipitate that formed after $16 \mathrm{hr}$ at $4^{\circ}$ was washed with $80 \%$ ethanol and dried with ether. Glycosaminoglycan fractions were characterized by sequential enzymic digestion with Varidase and testicular hyaluronidase. Undigested glycosaminoglycans were precipitated by the addition of 4 volumes of ethanol to the digests and incubating for $5 \mathrm{hr}$ at $4^{\circ}$.

\section{ANALYTIC METHODS}

Uronic acid was assayed by the method of Bitter and Muir (3). Total hexosamine, glucosamine, and galactosamine were determined using an automatic amino acid analyzer after samples were hydrolyzed for $20 \mathrm{hr}$ in $6 \mathrm{~N} \mathrm{HCl}$ in a sealed tube.

Paper chromatography was performed on Whatman no. 3MM paper with descending development in the following solvents: solvent A, $1 \mathrm{M}$ ammonium acetate, pH 5.0-ethanol $(3: 7, \mathrm{v} / \mathrm{v})$; solvent $\mathrm{B}$, isobutyric acid-aqueous $2.0 \mathrm{M} \mathrm{NH}_{3}(5: 3, \mathrm{v} / \mathrm{v})$; and solvent $C$, pyridine-ethyl acetate-water $(1: 2: 2, v / v / v)$. Boratetreated paper was used with solvent $C$.

\section{RESULTS}

The data in Table 1 indicate synthesis as measured by incorporation of $\left[\mathrm{U}^{-3} \mathrm{H}\right]$ acetate and content of glycosaminoglycans as measured by uronic acid. Not included are data for
${ }^{35} \mathrm{SO}_{4}$ incorporation which showed the same distribution for sulfated glycosaminoglycans. Four different glycosaminoglycans were detected: hyaluronic acid, chondroitin sulfate, dermatan sulfate, and heparan sulfate. $\left[{ }^{3} \mathrm{H}\right]$ Acetate was incorporated into all four glycosaminoglycans and ${ }^{35} \mathrm{SO}_{4}$ into the three sulfated glycosaminoglycans. These results show that hyaluronic acid and other glycosaminoglycans are present and are actively synthesized in Wilms' tumor.

Figure 1 shows the elution profiles obtained when labeled glycosaminoglycans were fractionated on columns of Sephadex G-50 after sequential enzymic and chemical degradation. All of the labeled and uronic acid-containing material was eluted in the void volume of the column of Sephadex G-50 (Fig. 1A). After treatment of the excluded fractions with Varidase, the resulting hyaluronic acid and chondroitin disaccharides were separated from undigested material in the void volume (Fig. $1 B$ ) and identified by paper chromatography in solvent $A$. Subsequent treatment of the undigested material with testicular hyaluronidase followed by treatment of the testicular hyaluronidase-resistant material with chondroitinase $A B C$ allowed the identification of dermatan sulfate and chondroitin sulfate fractions, respectively (Fig. $1, C$ and $D$ ). After chondroitinase $\mathrm{ABC}$ digestion, the resistant material was treated with nitrous acid to identify heparan sulfate. Practically all of the ${ }^{35} \mathrm{SO}_{4}$ labeled material moved to an included position on Sephadex G50 (Fig. $1 E$ ).

PROPERTIES OF HYALURONIC ACID AND SULFATED GLYCOSAMINOGLYCANS ISOLATED FROM WILMS' TUMOR

The reaction mixture obtained following alkali digestion of Wilms' tumor was fractionated by ion-exchange chromatography on a column of ECTEOLA-cellulose. Two peaks of uronic acid-containing material corresponding with the two major peaks of radioactivity are apparent (Fig. 2, fractions E-1 and E2). Approximately $80 \%$ of the total uronic acid-containing material was eluted in fraction E-1. Both fractions $E-1$ and $E-2$ contain $\left[{ }^{3} \mathrm{H}\right]$ acetate-labeled material whereas the ${ }^{35} \mathrm{SO}_{4}$-labeled material was confined to fraction E-2.

Fraction E-1 contained glucosamine as the sole amino sugar and uronic acid in a molar ratio of 0.95:1.00. All of the uroniccontaining and $\left[{ }^{3} \mathrm{H}\right]$ ace tate-labeled material in fraction $\mathrm{E}-1$ was eluted in the void volume of a column of Sepharose 4B. This void volume material was completely digested with streptococcal hyaluronidase to yield a product with the same $R_{F}$ value on paper chromatography in solvent $A$ as the disaccharide produced from authentic hyaluronic acid. The $\left[{ }^{3} \mathrm{H}\right]$ acetate-labeled and uronic-containing material in fraction E-1 migrated as a single

Table 1. Characterization of glycosaminoglycans isolated from Wilms' tumor and cells derived from Wilms' tumor ${ }^{1}$

\begin{tabular}{|c|c|c|c|c|}
\hline & \multicolumn{2}{|c|}{ Solid tumor } & \multicolumn{2}{|c|}{ Cultured cells } \\
\hline & $\begin{array}{c}{\left[{ }^{3} \mathrm{H}\right]-} \\
\text { Acetate, } \\
\mathrm{cpm} / \mathrm{g}\end{array}$ & $\begin{array}{l}\text { Uronic } \\
\text { acid, } \\
\mu \mathrm{g} / \mathrm{g}\end{array}$ & $\begin{array}{c}{\left[{ }^{3} \mathrm{H}\right]-} \\
\text { Acetate, } \\
\text { cpm } / 10^{6} \\
\text { cells }\end{array}$ & $\begin{array}{c}{\left[{ }^{14} \mathrm{C}\right]-} \\
\text { Gluco- } \\
\text { samine, } \\
\text { cpm } / 10^{6} \\
\text { cells }\end{array}$ \\
\hline Total glycosaminoglycans & 119,000 & 514 & 7,500 & 10,800 \\
\hline Hyaluronic acid & 71,000 & 400 & 5,300 & 8,100 \\
\hline Chondroitin & 1,000 & - & 100 & 200 \\
\hline Chondroitin sulfate & 33,000 & 102 & 1,100 & 1,400 \\
\hline Dermatan sulfate & 6,000 & 6 & 700 & 600 \\
\hline Heparan sulfate & 8,000 & 6 & 300 & 500 \\
\hline
\end{tabular}

${ }^{1}$ Wilms' tumor $(14 \mathrm{~g})$ and cells $\left(10^{7}\right.$ cells/plate) were incubated with $\mathrm{H}_{2}{ }^{35} \mathrm{SO}_{4}$ and $\left[{ }^{3} \mathrm{H}\right]$ acetate or $\left[{ }^{14} \mathrm{C}\right.$ lglucosamine and the glycosaminoglycans isolated and fractionated as described under Methods. Values are expressed per $g$ wet weight of tumor or $10^{6}$ cells. 


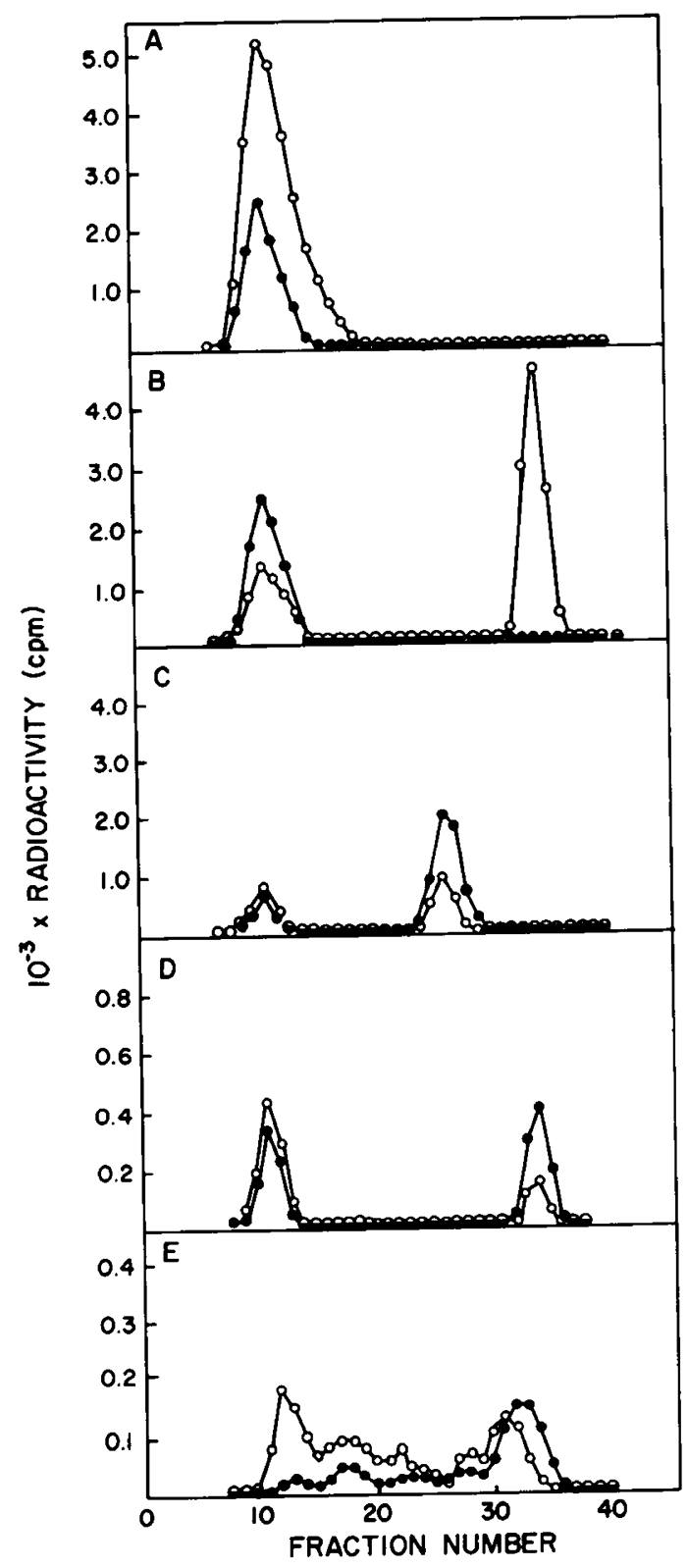

Fig. 1. Gel chromatography of double labeled material isolated from Wilms' tumor mince incubation mixtures after sequential enzymic and chemical treatments. Treatments were done on the void volume material as indicated under Methods in the following sequence: A, none; B, streptococcal hyaluronidase; C, testicular hyaluronidase; D, chondroitinase $\mathrm{ABC} ; \mathrm{E}$, nitrous acid. Fractions were approximately $4.5 \mathrm{ml} ;{ }^{35} \mathrm{SO}_{4}$ content $(-\bullet)$ and $\left[{ }^{3} \mathrm{H}\right]$ acetate content $(\mathrm{O}-\mathrm{O})$ are shown.

spot with an electrophoretic mobility similar to authentic hyaluronic acid (18).

Hyaluronic acid was also isolated from Wilms' tumor by fractionation of a Pronase digest of the tissue on Sepharose 4B. All of the hyaluronic acid was eluted in the void volume of the column of Sepharose 4B. Approximately $1 \mathrm{mg}$ hyaluronic acid was obtained per $g$ wet weight tissue. This preparation had a molecular weight of greater than $2.0 \times 10^{6}$ estimated from its viscosity number of $4800 \mathrm{ml} / \mathrm{g}$ determined by Dr. Martin B. Mathews using a Ubbeholde suspended level viscometer. These results show clearly that Wilms' tumor actively incorporates label into hyaluronic acid and that the uronic acid-containing and $\left[{ }^{3} \mathrm{H}\right]$ acetate-labeled product in fraction $\mathrm{E}-1$ is hyaluronic acid.
Fraction E-2 (Fig. 2) contained all of the ${ }^{35} \mathrm{SO}_{4}$ label of the original reaction mixture. Sequential enzymic and chemical degradation, by the method outlined in Figure 1, showed this fraction to contain $85 \%$ chondroitin sulfate, $6 \%$ dermatan sulfate, and $9 \%$ heparan sulfate (based on uronic acid analyses). These results are similar to those obtained for the alkali-soluble fraction reported in Table 1.

Before enzymic digestion most of the sulfate-labeled material was eluted at the void volume of a column of Sephadex G-200 indicating that the molecular weight of the sulfated glycosaminoglycan chains is greater than $40,000(14)$. Fifty-seven percent, $23 \%$, and $20 \%$ of the $\left[{ }^{3} \mathrm{H}\right]$ acetate in the chondroitinase $\mathrm{ABC}$ sensitive material in fraction $\mathrm{E}-2$ co-chromatographed in solvent $B$ with $\Delta$ di Ch-6S (35), $\Delta$ di $C h-4 S$, and $\Delta$ di $C h$, respectively. Based on elution from a column of Sephadex G-200, the chondroitinase ABC-resistant material, which was identified as heparan sulfate by its degradation with nitrous acid, has an average chain length of approximately 25,000 (13).

\section{GLYCOSAMINOGLYCAN SYNTHESIS BY CULTURED WILMS' TUMOR CELLS}

Although the cells derived from Wilms' tumor were not cloned, they appeared to be uniform in structure and did not readily attach to tissue culture dishes. Both $\left[{ }^{3} \mathrm{H}\right]$ acetate and $\left[{ }^{14} \mathrm{C}\right]$ glucosamine are readily incorporated into hyaluronic acid and sulfated glycosaminoglycans (Table 1). Label was incorporated into the same four glycosaminoglycans found in minced tumor incubations. Hyaluronic acid was separated from the sulfated glycosaminoglycans by ion-exchange chromatography of the soluble glycosaminoglycans on ECTEOLA-cellulose. The profile of radioactivity obtained was similar to the one shown in Figure 2. Ninety-eight percent of the labeled hexosamine present in the acid hydrolysate of $\left[{ }^{14} \mathrm{C}\right]$ glucosamine-labeled hyaluronic acid component cochromatographed on paper after $N$ acetylation with $N$-acetylglucosamine in solvent $\mathrm{C}$.

\section{INCORPORATION OF RADIOACTIVITY FROM UDP DERIVATIVES INTO HYALURONIC ACID}

A particulate enzyme system, isolated from $20 \mathrm{~g}$ Wilms' tumor and assayed for hyaluronic acid biosynthetic activity as described by Hopwood et al. (13), actively incorporated label from UDP- $\left[{ }^{14} \mathrm{C}\right] \mathrm{GIcUA}$ and UDP- $\left[{ }^{14} \mathrm{C}\right] \mathrm{GIcNAc}$ into hyaluronic

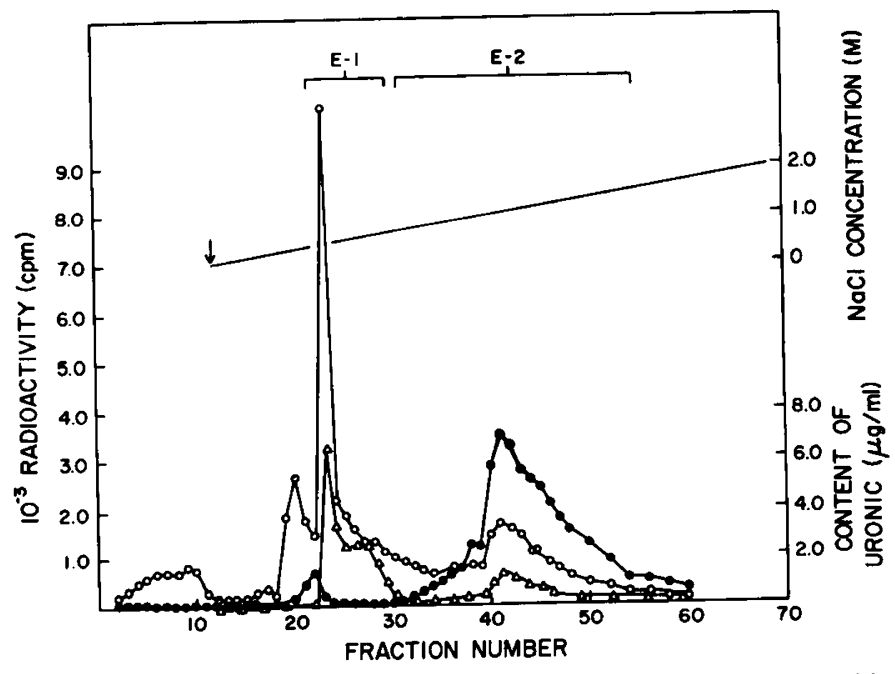

Fig. 2. Elution from a column of ECTEOLA-cellulose of the soluble products obtained from Wilms' tumor after incubation with ${ }^{35} \mathrm{SO}_{4}$ and $\left[{ }^{3} \mathrm{H}\right]$ acetate and extraction with $0.5 \mathrm{M} \mathrm{KOH}$ as outlined under Methods. Fractions were eluted from ECTEOLA-cellulose, starting at fraction 12 , with a linear gradient of $\mathrm{NaCl}$. Fractions were approximately $17 \mathrm{ml}$; ${ }^{35} \mathrm{SO}_{4}$ content $(-\bullet),\left[{ }^{3} \mathrm{H}\right]$ acetate $\left(\mathrm{O}_{-}-\mathrm{O}\right)$, and uronic acid content $(\triangle-\Delta)$ are shown. 
Table 2. Glycosaminoglycan content of serum and urine from Wilms' tumor patient ${ }^{1}$

\begin{tabular}{lcc}
\hline \multicolumn{1}{c}{ Enzyme treatment } & $\begin{array}{c}\text { Serum, } \\
\mathrm{mg} / 100 \mathrm{ml}\end{array}$ & $\begin{array}{c}\text { Urine, } \\
\mathrm{mg} / 100 \mathrm{ml}\end{array}$ \\
\hline None & 26.0 & 25.0 \\
Streptococcal hyaluronidase & 5.8 & 6.0 \\
Testicular hyaluronidase & 2.0 & 1.4 \\
\hline
\end{tabular}

${ }^{1}$ Serum and urine samples were treated as outlined under Methods. Values shown are for hexuronic acid-positive material, insoluble in ethanol after digestion of fractions with either streptococcal or testicular hyaluronidase.

acid. Eighty-five percent of the labeled material was eluted in the void volume of a column of Sepharose 4B. More than $90 \%$ of the excluded labeled material was degraded with streptococcal hyaluronidase to produce a disaccharide with the same mobility on paper as $\Delta \mathrm{di} \mathrm{HA}$ in solvent A. Approximately $15 \mathrm{nmol}$ GlcUA and $20 \mathrm{nmol}$ GlcNAc/hr/mg protein were incorporated into hyaluronic acid by the Wilms' tumor particulate enzyme system. This level of hyaluronic acid biosynthetic activity is similar to that reported for a particulate system isolated from a rat fibrosarcoma (14) and considerably higher than that described for particulate fractions isolated from other mammalian tissues $(22,27,30)$.

\section{GLYCOSAMINOGLYCAN CONTENT OF SERUM AND URINE SAMPLES}

Approximately $26 \mathrm{mg}$ and $25 \mathrm{mg}$ glycosaminoglycan were isolated $/ 100 \mathrm{ml}$ serum and urine, respectively (Table 2). Eighty percent of the total hexosamine in the acid hydrolysate of the glycosaminoglycan fractions isolated from serum and urine was glucosamine. After digestion of the isolated glycosaminoglycan fraction with streptococcal hyaluronidase, $5.8 \mathrm{mg}$ and $6.0 \mathrm{mg}$ of glycosaminoglycan $/ 100 \mathrm{ml}$ serum and urine, respectively, were precipitable with ethanol (Table 2). Most of the streptococcal hyaluronidase-resistant material was sensitive to digestion with testicular hyaluronidase (Table 2). These results indicate that the serum fraction contains approximately $19 \mathrm{mg}$ hyaluronic acid and $4.6 \mathrm{mg}$ chondroitin sulfate $/ 100 \mathrm{ml}$.

\section{DISCUSSION}

Hyaluronic acid, which is present normally only in trace amounts in serum or urine $(6,33)$, was found in high concentration together with elevated levels of chondroitin sulfate in the serum and urine of a patient with a Wilms' tumor. Similar levels of hyaluronic acid in the serum and urine of Wilms' tumor patients have been reported by others $(4,7,21,24,29)$. However, the elevated levels of chondroitin sulfate in the serum and urine have not previously been demonstrated and differ with the finding by Morse and Nussbaum (21) that sulfate ester groups could not be detected in the glycosaminoglycan fraction which they isolated from the serum of a Wilms' tumor patient. The reason for this difference is not understood: it may have resulted from the different methods used to isolate glycosaminoglycans from serum or it may reflect differences in the rate of glycosaminoglycan synthesis or catabolism in different Wilms' tumors or between individuals.

The high levels of hyaluronic acid in the tumor are in contrast to the amount of hyaluronic acid in normal kidney (32). The finding that hyaluronic acid is present in high concentrations in serum, urine, and the tumor and that surgical removal of the tumor results in the disappearance of hyaluronic acid from the serum of these patients (24), has provided only circumstantial evidence that the circulating hyaluronic acid is synthesized by the tumor. The evidence reported in the present paper shows directly that hyaluronic acid and chondroitin sulfate are synthesized at very high levels in minced tissue, cultured cells, and cell-free preparations from Wilms' tumor. Although cultured cells were not cloned, their isolation over agar and morphology indicated that they were tumor cells rather than fibroblasts.

Hyaluronic acid has recently been implicated in such processes as cell aggregation $(23,34)$ and mesenchymal cell mobility $(17$, 31). Powars et al. (24) have speculated that hyaluronic acid may be involved in the growth and control of metastasis of Wilms' tumor. Beierle et al. (2) have reported that the serum of patients with Wilms' tumor or a crude glycosaminoglycan fraction isolated from Wilms' tumor selectively enhances the growth of cultured kidney or lung cells. Burtin and Gendron (5) have prepared antisera against extracts of Wilms' tumor and have suggested that the antigen may be viral in origin. Nephroblastomas in hamsters that had received kidney hamster cells transformed with simian virus 40 have been observed (19). Hamsters inoculated intravenously with simian virus 40 developed neoplasms (8). Enders (10) observed that a neoplasm in hamsters that developed after implantation of simian virus 40-transformed hamster kidney cells displayed Wilms'-like histology.

We have shown recently that after transformation with simian virus 40 cultured human skin fibroblasts exhibit greatly increased hyaluronic acid biosynthetic capacity together with the loss of cell density-dependent inhibition of growth (12). All of these findings tend to favor speculation that the loss of control over cell proliferation in these tumors may be related to their marked increase in synthesis of hyaluronic acid. Regardless of this speculation, the finding reported in the present paper that Wilms' tumor is very active in hyaluronic acid synthesis provides another system in which the mechanism and control of hyaluronic acid synthesis may be studied.

\section{REFERENCES AND NOTES}

1. Allerton, S. E., Beierle, J. W., Powars, D. R., and Bavetta, L. A.: Abnormal extracellular components in Wilms' tumor. Cancer Res., 30: 679 (1970).

2. Beierle, J. W., Heimerl, D. M., Allerton, S. E., and Bavetta, L. A.: Growth promotion by extractions from Wilms' tumor in vitro. Experientia, 27: 435 (1971).

3. Bitter, T., and Muir, H. M.: A modified uronic acid carbazole reaction. Anal. Biochem., 4: 330 (1962).

4. Broughton, P. M. G., Dykes, J. R. W., Holt, S., Ridley, J. W., and Steel, A. E.: Mucopolysaccharides in the blood of a patient with neuroblastoma. J. Clin. Pathol., 23: 246 (1970).

5. Burtin, P., and Gendron, M. C.: A tumor-associated antigen in human nephroblastomas. Proc. Natl. Acad. Sci. U. S. A., 70: 2051 (1973).

6. Calatroni, A., Donnelly, P. V., and Di Ferrante, N.: The glycosaminoglycans of human plasma. J. Clin. Invest., 48: 332 (1969).

7. Deutsch, H. F.: Some properties of a human serum hyaluronic acid. J. Biol Chem., 224: 767 (1957).

8. Diamandopoulos, G. T.: Induction of lymphocytic leukemia, lymphosarcoma, reticulum cell sarcoma and osteogenic sarcoma in the syrian golden hamster by oncogenic DNA simian virus 40. J. Natl. Cancer Inst., 50: 1347 (1973)

9. Dorfman, A., and Ho, P.-L.: Synthesis of acid mucopolysaccharides by glial tumor cells in tissue culture. Proc. Natl. Acad. Sci. U. S. A., 66: 495 (1970).

10. Enders, J. F.: Cell transformation by viruses as illustrated by the response of human and hamster renal cells to simian virus 40 . The Harvey Lectures, Series 59, pp. 113-153 (Academic Press, New York, 1965).

11. Galligani, L., Hopwood, J. J., Schwartz, N. B., and Dorfman, A.: Stimulation of synthesis of free chondroitin sulfate chains by $\beta$-D-xylosides in cultured cells. J. Biol. Chem., 250: 5400 (1975).

12. Hopwood, J. J.: Glycosaminoglycan synthesis in cultured simian virus 40 transformed human skin fibroblasts. Fed. Proc., 33: 1557 (1974).

13. Hopwood, J. J., Fitch, F. W., and Dorfman, A.: Hyaluronic acid synthesis in a cell-free system from rat fibrosarcoma. Biochem. Biophys. Res. Commun., 6I: 583 (1974).

14. Hopwood, J. J., and Robinson, H. C.: The molecular weight distribution of glycosaminoglycans. Biochem. J., 135; 631 (1973).

15. Kimmel, J. R., and Smith, E. L.: Crystalline papain. J. Biol. Chem., 207: 515 (1954).

16. Lagunoff, D., and Warren, G.: Determination of 2-deoxy-2-sulfoaminohexose content of mucopolysaccharides. Arch. Biochem. Biophys., 99: 395 (1962).

17. Margolis, R. U., Margolis, R. K., Chang, L. B., and Preti, C.: Glycosaminoglycans of brain during development. Biochemistry, 14: 85 (1975).

18. Matalon, R. and Dorfman, A.: Hurler's syndrome: Biosynthesis of acid mucopolysaccharides in tissue culture. Proc. Natl. Acad. Sci. U. S. A., 56: 1310 (1966).

19. May, E.: Recherche sur l'infection abortive et la transformation par le SV40 de cellules renales de souris en cultures primaires confluentes. These doctorates Sciences, Universite de Paris (1972) as quoted by Burtin and Gendron.(5). 
20. Meyer, K., and Rapport, M. M. In: F. F. Nord: Advances in Enzymology, Hyaluronidases, Vol. 13, pp. 199-236 (Interscience Publishers, Inc., New York, 1952).

21. Morse, B. S., and Nussbaum, M.: The detection of hyaluronic acid in the serum and urine of a patient with nephroblastoma. Amer. J. Med., 42: 996 (1967).

22. Österlin, S. W., and Jacobson, B.: The synthesis of hyaluronic acid in vitreous. Exp. Eye Res., 7: 497 (1968).

23. Pessac, B., and Defendi, V.: Cell aggregation: Role of acid mucopolysaccharides. Science, 175: 898 (1972)

24. Powars, D. R., Allerton, S. E., Beierle, J., and Butler, B. B.: Wilms' tumor clinical correlation with circulating mucin in three cases. Cancer, 29: 1597 (1972).

25. Robinson, H. C., and Hopwood, J. J.: The alkali cleavage and borohydride reduction of cartilage proteoglycans. Biochem. J., 133: 457 (1973).

26. Saito, H., Yamagata, T., and Suzuki, S.: Enzymatic methods for the determination of small quantities of isometric chondroitin sulfates. J. Biol. Chem., 243: 1536 (1968)

27. Schiller, S., Slover, G. A., and Dorfman, A.: The synthesis of hyaluronic acid by cell-free extracts of embryonic skin. Biochem. Biophys. Res. Commun., 5: 344 (1961).

28. Silbert, J. E.: Incorporation of ${ }^{14} \mathrm{C}$ and ${ }^{3} \mathrm{H}$ from labeled nucleotide sugars into polysaccharide in the presence of a cell-free preparation from cartilage. J. Biol. Chem., 239: 1310 (1964).

29. Tomasi, T. B., Jr., Robertson, W. V. B., Naeye, R., and Reichlin, M.: Serum hyperviscosity and metabolic acidosis due to circulating hyaluronic acid. J. Clin. Invest., 45: 1080 (1966).

30. Tomida, M., Koyama, H., and Ono, T.: Hyaluronic acid synthetase in cultured mammalian cells producing hyaluronic acid. Biochim. Biophys. Acta, 338: 352 (1974)

31. Toole, B. P., Jackson, G. and Gross, J.: Hyaluronate in morphogenesis: Inhibition of chondrogenesis in vitro. Proc. Natl. Acad. Sci. U. S. A., 69: 1384 (1972).

32. Van Praag, D., Stone, A. L., Richter, A. J. and Farber, S. J.: Composition of glycosaminoglycans (mucopolysaccharides) in rabbit kidney. II. Renal cortex. Biochim. Biophys. Acta, 273: 149 (1972).

33. Varadi, D. P., Cifonelli, J. A. and Dorfman, A.: Acid mucopolysaccharides in normal urine. Biochim. Biophys. Acta, 141: 103 (1967)

34. Wasteson, $\AA$., Westermark, B., Lindahl, U., and Ponten, J.:Aggregation of feline lymphoma cells by hyaluronic acid. Int. J. Cancer, 12: 169 (1973).

35. The abbreviations used are: $\Delta$ di Ch-S, 3-O- $\beta-\Delta-4,5$-glucuronosyl- $N$-acetyl-Dgalactosamine-6-O-SO $; \Delta$ di Ch-4S, 3-O- $\beta-\Delta-4,5$-glucuronosyl- $N$-acetyl-Dgalactosamine-4-O-SO$; \Delta$ di $C h, 3-O-\beta-\Delta-4,5$-glucuronosyl- $N$-acetyl-D-galactosamine; $\Delta$ di HA, 3-O- $\beta-\Delta-4,5$-glucuronosyl- $N$-acetyl-D-glucosamine.

36. The authors are grateful to Drs. Emily Pang and John Moohr for providing us with the Wilms' tumor, urine, and plasma supplies.

37. This investigation was supported by NIH Grants AM-05996, HD-04583 and HD-09402 and by the Home for Destitute Crippled Children.

38. Dr. John J. Hopwood is a Kennedy Fellow in the Neurosciences. Present address: Department of Chemical Pathology, Adelaide Children's Hospital, North Adelaide, S. A. 5006 (Australia).

39. Requests for reprints should be addressed to: Albert Dorfman, M.D. University of Chicago, Department of Pediatrics, 950 East 59th Street, Hospital Box 413, Chicago, IL 60637 (USA).

40. Received for publication February 15,1977

41. Accepted for publication April 5, 1977.

\title{
Letter to the Editor: Metabolic Studies in Tyrosinemia
}

\author{
NEIL R. M. BUIST, ${ }^{(13)}$ JACK H. FELLMAN, AND NANCY KENNAWAY
}

University of Oregon, Health Sciences Center, Portland, Oregon

The article by K. F. Faull and his colleagues entitled "Metabolic Studies on Two Patients with Non-hepatic Tyrosinemia Using Deuterated Tyrosine Loads" (3) raises several points which appear to us to require comment. The term "non-hepatic tyrosinemia" is inappropriate for a disorder in which hepatic enzymes are alleged to be deficient and only serves to complicate the present nomenclature. The tyrosinemia which is associated with liver damage and a Fanconi syndrome is clinically quite distinct from the tyrosinemia associated with eye and skin lesions and mental retardation without liver damage. In order to distinguish these two clinical entities we have called them type 1 and type 2, respectively (2).

The enzyme assays in Dr. Faull's study are critically inadequate. Since liver contains a nonspecific mitochondrial transaminase (aspartate aminotransferase) capable of accepting tyrosine as substrate (11) any meaningful investigation of tyrosine aminotransferase must be carried out on supernatant fractions of liver homogenates $(7,8)$. Granner's method requires the use of diethyldithiocarbamate as an inhibitor of hydroxylase activity in fresh liver samples and this was not employed. Moreover, saturating concentrations of substrate were not present in the assay for $p$-hydroxyphenylpyruvate hydroxylase activity even if all the $\left[{ }^{14} \mathrm{C}\right]$ tyrosine was converted to ketoacid. Finally, the choice of a paper chromatographic procedure is baffling when more simple, sensitive, and accurate methods already exist $(5$, $10,12)$.

The $\left[{ }^{2} \mathrm{H}\right]$ tyrosine experiments are predicated on the retention of the ${ }^{2} \mathrm{H}$ on the phenolic ring during its metabolic passage. This must be constant for any meaningful interpretation of these experiments. Under physiologic conditions, ${ }^{2} \mathrm{H}$ exchange at the ortho position of tyrosine could be considerably greater than under the strong acid conditions employed by the authors to establish stability of the labeling. We thus have no means of interpreting the reported urinary metabolic results which might vary with storage and even with the $\mathrm{pH}$ of the urine. Indeed, the ${ }^{2} \mathrm{H}$ study may be more misleading than instructive. The $\left[{ }^{2} \mathrm{H}\right]$ tyrosine load $(120 \mathrm{mg} / \mathrm{kg})$ could not dissolve in $100 \mathrm{ml}$ as described by the authors; moreover, at the $\mathrm{pH}$ of ileal fluid, the solubility is only about $750 \mathrm{mg} /$ liter. The stool content of ${ }^{2} \mathrm{H}$ compounds is not mentioned and failure of absorption could account for a substantial proportion of the load. Some evidence for this is apparent from the 165-fold increase in urinary $p$ hydroxyphenylacetate after ${ }^{2} \mathrm{H}$-tyrosine load in their normal subject. It has been established that the bulk, if not all, of the urinary $p$-hydroxyphenylacetate originates from gut bacterial action on tyrosine $(1,6)$. Furthermore, the blood levels of $\left[{ }^{2} \mathrm{H}\right]$ tyrosine in patients continued to increase for $8 \mathrm{hrs}$, which also suggests delayed absorption of the amino acid from the gut. 